\title{
PIESŇOVÝ REPERTOÁR OBCE JABLONICA NA ZÁHORÍ A „ZDOBENÝ SPEV“ V ZÁPISOCH KAROLA PLICKU
}

\section{Miriam Timková}

Mgr. Miriam Timková, PhD.; Ústav hudobnej vedy SAV, Dúbravská cesta 9, 84104 Bratislava 4; e-mail: miriam.timkova@savba.sk

\section{Abstract}

\begin{abstract}
In his collecting activity in Slovakia Karol Plicka (1894 - 1987) gave particular attention to the Záhorie region. Taking the example of the village of Jablonica in the eastern part of this region, we demonstrate the collector's interest in the local song repertoire, individual singers, and the specific vocal style of ornamentation in Záhorie. Using source criticism, a repertoire was identified to the extent of 187 songs, recorded from 26 singers in this locality. Particularly useful are the written records of songs by the singers Pavol Pinkava and Agneša Pinkavová. Their song repertoire contains principally ballads, wedding, dance and love songs. In his studies the collector also gave particular attention to Pavol Pinkava as an individual singer: the records of embellished singing as rendered by this singer are comparable to the records of the singing of Eva Studeničová, an outstanding singer from the village of Moravský sv. Ján in the western part of Záhorie. The records of songs performed by other singers are instructive as regards observation of song variants, and they highlight the contemporary condition and preservation of folk singing in local tradition.
\end{abstract}

Key words: local repertoire, bearers of song tradition, variants of songs, embellished singing

\section{Úvod}

Výsledkom zberatel'skej činnosti Karola Plicku na Slovensku je rozsiahla rukopisná zbierka, ktorá predstavuje jeden z najvýznamnejších prameňov slovenskej ludovej piesne z prvej polovice 20 . storočia. ${ }^{1}$ Ako sme vo viacerých štúdiách upozornili, práca

1 URBANCOVÁ, Hana: Vybrané kapitoly z dejín slovenskej etnomuzikológie. Bratislava : Ústav hudobnej vedy SAV, 2016, s. 128. URBANCOVÁ, Hana: Rukopisná zbierka slovenských ludových 
s Plickovými zápismi je pomerne komplikovaná nielen z hladiska spôsobu zápisu, ale aj z hladiska súčasného stavu uloženia celej rukopisnej zbierky. ${ }^{2}$ Vzhladom na to, že jednotlivé časti tejto zbierky sa nachádzajú uložené v dvoch inštitúciách, konkrétne v Slovenskom národnom múzeu (Pozostalost' K. Plicku, dalej SNM) ${ }^{3}$ a v Slovenskej národnej knižnici - Literárnom archíve (d’alej SNK-LA) ${ }^{4}$ v Martine, pri výskume sme museli porovnávat’ a dopĺňat zápisy z obidvoch zdrojov. Na základe viacročnej systematickej práce s Plickovými rukopisnými zápismi sme vytvorili metodický systém, ktorý sme opísali už v predchádzajúcich štúdiách. ${ }^{5}$ Tento systém práce s Plickovými zápismi sme použili aj v prípade jeho záznamov z obce Jablonica na Záhorí.

Po spracovaní Plickových zápisov zo stredného Považia sa budeme postupne venovat rekonštrukcii jeho zápisov z regiónu Záhorie. Ako jednu z prvých záhorských obcí, kde K. Plicka uskutočnil terénny výskum, sme zvolili Jablonicu, nachádzajúcu sa vo východnej časti Záhoria. Na túto lokalitu sme sa zamerali prednostne aj preto, že podla charakteru piesňových zápisov (prevažne v podobe melodických čistopisov s textom, prípadne samostatne zapísaným textom) bol zrejmý nielen intenzívny záujem zberatela o túto lokalitu, ale pravdepodobne aj úmysel d’alšej práce s realizovanými zápismi. Okrem iného nás zaujal fakt, že K. Plicka v tejto obci zaznamenal ozdobný spev, podobne ako ho dokumentoval aj v obci Moravský Svätý Ján v podaní výnimočnej speváčky Evy Studeničovej. ${ }^{6}$ Jablonica sa nachádza v Trnavskom kraji a dnes patrí do okresu Senica. ${ }^{7}$

\section{Rekonštrukcia piesňových zápisov a rozsah repertoáru}

Pri rekonštrukcii Plickových piesňových zápisov z Jablonice sme vychádzali najmä z prameňov nachádzajúcich sa v SNM, pričom tieto zápisy nie sú signované. ${ }^{8}$ Vyskytovali sa prevažne $\mathrm{v}$ podobe melodických čistopisov s podpísaným piesňovým textom, prípadne sa text piesne nachádzal na samostatnom záznamovom lístku v podobe textového prvopisu. Na základe zápisov zo SNM sme zostavili abecedný zoznam

piesní Karola Plicku - otázky evidencie a spracovania prameňov. In: Od lidové písně k evropské etnologii. 100 let Etnologického ústavu Akademie věd České republiky. Ed. Jana Pospišilová, Jana Nosková. Brno : Etnologický ústav AV ČR, 2006, s. 232-244.

2 TIMKOVÁ, Miriam: Piesňový repertoár obce Dohňany. Zo zápisov Karola Plicku. In: Musicologica Slovaca, roč. 2 (28), 2011, č. 2, s. 251-273. TIMKOVÁ, Miriam: Piesne z obce Lazy pod Makytou v zápisoch Karola Plicku. In: Musicologica Slovaca, roč. 4 (30), 2013, č. 1, s. 104-136. TIMKOVÁ, Miriam: Pozostalost' Karola Plicku a problémy jej spracovania. In: Musicologica Slovaca, roč. 6 (32), 2015, č. 1, s. 62-85.

3 Pôvodne Etnografické múzeum v Martine.

4 Pôvodne Matica slovenská v Martine.

5 TIMKOVÁ, Ref. 2.

6 TIMKOVÁ, Miriam: Rekonštrukcia piesňového repertoáru Evy Studeničovej zo zápisov Karola Plicku. In: Musicologica Slovaca, roč. 7 (33), 2016, č. 2, s. 249-283.

7 Encyklopédia miest a obcí Slovenska. Banská Bystrica : PS-Line, 2005, s. 147.

8 Momentálne sa tieto zápisy nachádzajú v škatuli č. 3, v troch samostatných nami vytvorených obaloch, ktoré sú sústredené do jedného hlavného obalu pod názvom „Jablonica“. (Názvy jednotlivých obalov: „Jablonica - texty, riekanky“; „Jablonica - textové / melodické prvopisy“; „Jablonica - skompletizované melodické zápisy + texty“). 
textových incipitov, ktorý sa stal základom našej d’alšej práce so zápismi uloženými v SNK-LA. Zápisy z Jablonice sa tu nachádzajú pod týmito signatúrami: A VII 3242 - 3 244; A VII 3273 - 3 276; A VII 3 284; A VII 20956 - 21 003; A VII 21006 - 21099. Piesňové zápisy sa prevažne vyskytujú vo forme odpisu cudzou rukou spolu aj s prepisom piesňového textu na stroji, d’alej vo forme Plickovho melodického čistopisu / melodického prvopisu, prípadne v podobe samostatného Plickovho textového prvopisu.

Pri práci s prameňmi uloženými v obidvoch inštitúciách sme často nachádzali omylom pripojené zápisy, ktoré pochádzali z iných lokalít okolia Jablonice (Osuské, Rozbehy a Hradište). Tieto zápisy sme samozrejme z výskumu vylúčili, pričom už pri revízii Plickovho fondu v 80-tych rokoch samotní pracovníci SNK-LA zistili, že niektoré záznamy sú stratené.

Výsledkom podrobnej komparačnej práce s prameňmi uloženými v obidvoch inštitúciách je piesňový repertoár v rozsahu 187 piesní. Z tohto celkového počtu sa v Plickovej pozostalosti v SNM nachádzajú aj 4 zápisy piesní, ktoré boli pôvodne uložené v SNK-LA, o čom nás informujú signatúry tejto inštitúcie. Objavili sme tiež 4 zápisy piesní, ktoré sa nachádzajú v oboch inštitúciách, t. j. čast’ zápisu piesne sa nachádza v SNM (napríklad melodický čistopis piesne) a čast’ v SNK-LA (napríklad jeho textový prvopis a podobne). Ďalších 107 zápisov sa nachádza iba v SNM a 72 zápisov len v SNK-LA.

Výsledok rekonštrukcie piesňových zápisov z Jablonice môžeme porovnat’s naším výskumom piesní zaznamenaných od Evy Studeničovej z Moravského Svätého Jána, pričom charakter zápisov a zberatel’ov prístup k nim je vel’mi podobný. Máme na mysli precíznu dokumentáciu piesní prevažne v podobe melodických čistopisov, a navyše - čo je pre Plicku ojedinelé - takmer pri každom zápise je uvedené aj meno speváka. Z celkového počtu piesní, ktoré Plicka v Jablonici zaznamenal, má až 181 piesní uvedenú nielen lokalitu, ale aj meno informátora. Iba v 6 prípadoch meno speváka nevieme, kedže Plicka ho zvykol uvádzat’ pri melodickom zápise piesne; z týchto piesní sa nám však zachovali iba textové prvopisy.

Ukázalo sa, že v obci Jablonica K. Plicka pracoval so širokým zázemím spevákov a speváčok. Z jeho zápisov sa nám podarilo identifikovat 26 mien, z ktorých sme vytvorili zoznam mien interpretov usporiadaný v abecednom poradí podla ich priezvisk. Vek uvádzame iba v prípade, ak bol pôvodne zberatelom zaznamenaný, pričom pri každom spevákovi a speváčke uvádzame aj počet zaznamenaných piesní.

1. Barcajová Cecília, [vek neuvedený] (2 piesne),

2. Bartáková Agáta, 32-ročná (8 piesní),

3. Blažková Mária, 13-ročná (1 pieseň),

4. Boltová Margita, [vek neuvedený] (1 pieseň),

5. Durgalová Kristína, 28-ročná (1 pieseň),

6. Gažová Anka, 37-ročná (5 piesní),

7. Hlásniček Jozef, 58-ročný (1 pieseň),

8. Jurovatá Angela, 12-ročná (1 pieseň),

9. Koblížková Anna, [vek neuvedený] (1 pieseň),

10. Lahotayová H., 15-ročná (1 pieseň),

11. Mihalová Elena, [vek neuvedený] (2 piesne), 
12. Nedbalová Mária, [vek neuvedený] (2 piesne),

13. Oslejová Mária, 53-ročná (18 piesní),

14. Patáková Anna, [vek neuvedený] (3 piesne),

15. Pinkava Pavel, 52-ročný (62 piesní),

16. Pinkavová Agneša, 35-ročná (40 piesní),

17. Pinkavová Julka, 15-ročná (2 piesne),

18. Polák Alfonz, 34-ročný (4 piesne),

19. Škápiková Katarína, 41-ročná (15 piesní),

20. Štebík Oto, [vek neuvedený] (1 pieseň),

21. Tesarová Herm.[-ína,] 12-ročná (1 pieseň),

22. Turanská Mária, [vek neuvedený] (2 piesne),

23. Valentová Katarína, 54-ročná (1 pieseň),

24. Valentová Mária, 50-ročná (3 piesne),

25. Žáková A., 10-ročná (1 pieseň),

26. Žáková Mária, [vek neuvedený] (2 piesne).

Ako zo zoznamu vyplýva, pri deviatich spevákoch nie je uvedený vek. Interpreti, s ktorými K. Plicka v tejto obci spolupracoval, tvorili rôznorodú skupinu, ktorá zahŕňala ako detských informátorov, tak aj dospelých. Ženy-speváčky predstavujú väčšinu (22 mien), z mužov sú to len štyria speváci. Uvedený pomer v zastúpení žien a mužov sa v podstate zhoduje s Plickovým názorom, že väčšinou sú spevácky aktívnejšie ženy, pričom je pre zberatela vel'kým problémom nájst' spol'ahlivého speváka - muža. ${ }^{9}$

Z dokumentovaného piesňového repertoáru nás najviac zaujali najmä kompletné Plickove zápisy od speváka Pavla Pinkavu, ktoré boli zároveň aj najpočetnejšie: zberatel' z podania tohto speváka zapísal 62 piesní. Podobne zaujímavé boli pre nás zápisy piesní, ktoré K. Plicka získal z podania Agneše Pinkavovej: ide o repertoár v rozsahu 40 piesní. Z celkového počtu 187 rekonštruovaných piesní z obce Jablonica zápisy piesní od týchto dvoch spevákov predstavujú viac ako polovicu repertoáru (102 zápisov), ktorý Plicka v tejto obci zaznamenal. Zvyšok (85 zápisov) tvoria piesne získané od d’alších informátorov $\mathrm{z}$ tejto lokality.

Jablonica, podobne ako Moravský Svätý Ján, spadá do oblasti, v ktorej sa v minulosti pravdepodobne vyskytoval v intenzívnejšom zastúpení ozdobný štýl spevu. Túto ozdobnost' vokálneho prejavu môžeme vidiet’ najmä v zápisoch piesní v podaní Pavla Pinkavu a Agneše Pinkavovej. ${ }^{10}$ Okrem týchto dvoch spevákov piesňové zápisy pochádzajú od d’alších 24 informátorov z Jablonice. V menšom počte sa tak vyskytujú zápisy piesní od týchto spevákov: Márie Oslejovej (18 piesní), Kataríny Škápikovej (15 piesní), Agáty Bartákovej (8 piesní). Pät piesní zapísal Plicka od Anky Gažovej a 4 piesne od Alfonza Poláka. Po 3 piesne zapísal od speváčok Anny Patákovej a Márie Valentovej. Od ostatných spevákov zapísal Plicka po jednej alebo dvoch piesňach, pričom ide najmä o detský folklór - riekanky, vyčítanky a rečňovanky či detské hry, napríklad: Kmotre! Copak ? (O. Štebík), Myšičko, myš (A. Patáková), Ťapy, tapy, ta-

$9 \quad$ PLICKA, Karol: Z ciest za slovenskou piesňou. In: Slovensko, roč. 1, 1934/1935, s. 138-140. URBANCOVÁ, Ref. 1, Vybrané kapitoly z dejín slovenskej etnomuzikológie, s. 128-130.

10 Príbuzenský vztah P. Pinkavu a A. Pinkavovej sa nám zatial’ nepodarilo zistit. 
pušky (A. Kobližková), Zlatá brana otevrita (H. Tesarová), Sedí kačer na barine (C. Barcajová), Šijeme mjechy na orechy (H. Lahotayová), Hajovia, hajovia (A. Žáková).

Vokálny štýl ozdobného spevu najviac dominuje v zápisoch piesní z podania Pavla Pinkavu a Agneše Pinkavovej, ale vyskytuje sa aj v piesňach v interpretácii Márie Oslejovej, Agáty Bartákovej a Kataríny Škápikovej. Od d’alších spevákov K. Plicka zaznamenal piesne v malom počte, pričom ozdobnost’ spevu je menej výrazná. Môžeme preto hypoteticky usudzovat', že podobne ako v prípade piesňových zápisov z Moravského Svätého Jána sa ozdobný spev aj tu pomaly vytrácal a všetci speváci v lokalite ho neovládali. Postupne začal dominovat’ spev v menej zdobenej forme, pričom ozdobný vokálny štýl vychádzal hlavne zo schopností a speváckeho potenciálu daného interpreta.

Žánrovú príslušnost’ piesní sa podarilo identifikovat’ pri 161 zápisoch; 26 piesní zostalo bez bližšieho určenia, pretože k nim chýbal záznam piesňového textu. Pri 6 piesňových zápisoch sa nám však podarilo dodatočne určit žánrovú príslušnost’ na základe porovnania s tlačenou zbierkou Záhorácké pjesňičky od Janka Blaha. ${ }^{11}$

Ozdobný spev sa vyskytuje hlavne v baladách, napríklad: V svatokaterinském háji, Čo sa stalo $v$ Trnave (K. Škápiková), Šla Anička do hajička, Na previjar švárnu ceru, Čo sa stalo $v$ nove (M. Oslejová). Zaujímavostou je napríklad balada Pásel Janko dva voly v podobe dvoch melodických variantov v podaní dvoch speváčok: Kataríny Škápikovej a Márie Oslejovej. Podla textu ide o zbojnícku baladu, pričom melodický variant od Márie Oslejovej je zdobený výraznejšie ako u Kataríny Škápikovej. Ďalej sa ozdobný spev vyskytuje v niektorých lúbostných piesňach, napríklad: Lecel, lecel roj, Tečie voda od Zahora mutná (K. Škápiková), Pred našima studňa múruvaná (M. Valentová), Šak je to smutný, neveselý deň, Daj mi, Bože, teho (M. Oslejová), A dubina, dubina, Chudobná devečka jako iskerečka, Zaspívaj slávičku, rozveseluj pole (A. Pinkavová); čiastočne aj v obradových piesňach, napríklad: Nové leto, nové („na Kvetnú nedelu“) od Agneše Pinkavovej. Vyskytuje sa aj v niektorých svadobných piesňach, napríklad: Zadala manka, zadala ceru (M. Oslejová), Ach, mamenko, mamko („ked idú s duchnami“) z podania Agneše Pinkavovej, či pri niektorých regrútskych piesňach, napríklad: Ked som mašíroval (A. Pinkavová).

Zriedkavejšie možno vidiet' výskyt ozdobného spevu pri niektorých tanečných piesňach, napríklad Ej, čača, čača (A. Pinkavová), ktorú K. Plicka označil ako „gajdošský tanec". Väčšinou však piesne k tancom ozdobný charakter nemajú, a to najmä, ak ide o rýchle tanečné piesne, napríklad Ej, okolo nás hlastovenka letala (K. Valentová). Pri tejto piesni sa nachádza Plickova poznámka: „chlapci skákajú, kerý výše!“, pričom ju uvádza ako pieseň „do skoku“.

V priadkovej piesni Practe, practe, pradulienky v podaní Agneše Pinkavovej však ozdobný charakter spevu absentuje. Podobne chýba aj v niektorých baladách, napríklad: Rúža Šandor bol zbojník (A. Bartáková) alebo v naratívnej piesni Počul som novinu v podobe dvoch melodických variantov v podaní Agneše a Julky Pinkavovej. Zdobený spev chýba aj v niektorých detských piesňach, humoristických piesňach či v dožinkovej piesni /:Pane náš:/, chystaj nám oldomáš (A. Bartáková).

11 BLAHO, Janko: Záhorácké pjesňičky. Ed. Peter Michalovič. Bratislava : Hudobné centrum, 2018. 
Z hladiska publikovaných Plickových zápisov piesní sme záznamy z Jablonice porovnali s vydanou zbierkou Slovenský spevník $I .{ }^{12} \mathrm{~V}$ tejto Plickovej tlačenej piesňovej zbierke sa vyskytujú tieto zápisy piesní z obce Jablonica:

1. Ach, mamenko moja - č. 17 (regrútska), s. 78, spev: Pavel Pinkava (SNK-LA, sign. A VII 21 024-21 025; súhlasí text aj melódia);

2. Chodievau Janíčok - č. 172 [žáner neuvedený], s. $170^{13}$ (pieseň sa nenachádza ani v SNM, ani v SNK-LA);

3. Jako si Janenko č. 201 (lúbostná), s. 187, spev: Agáta Bartáková (Pozostalost' K. Plicku, SNM v Martine; v tlačenej zbierke je pieseň transponovaná od tónu $a^{1}$, v rukopisnom zázname je nápev zapísaný v polohe od tónu $g^{1}$, inak text a melódia súhlasia);

4. Kebys' bola moja - č. 215 („do krepčená“, tanec mládencov pred muzikou, svadobná), s. 195, spev: Anka Gažová (SNK-LA, sign. A VII 21 045; súhlasí text aj melódia);

5. Ked já pojdem na francúzsku vojnu - č. 217 [žáner neuvedený], s. 196 (pieseň sa nenachádza ani v SNM, ani v SNK-LA);

6. Na levárskej veži - č. 269 [žáner neuvedený], s. 224 (pieseň sa nenachádza ani v SNM, ani v SNK-LA);

7. Na prahu stála - č. 275 (tanec „šúchaná“/regrútska), s. 228, spev: Katarína Škápiková (Pozostalost' K. Plicku, SNM v Martine; súhlasí text aj melódia);

8. Šak je to smutný, neveselý den - č. 381 (lúbostná, rozlúčková), s. 291, spev: Mária Oslejová (Pozostalost' K. Plicku, SNM v Martine; súhlasí text aj melódia);

9. Vysoko denička - č. 466 (lúbostná), s. 341, spev: Agáta Bartáková (SNK-LA, sign. A VII 21 078; súhlasí text aj melódia);

10. Zaspívaj slávičku, rozveseluj pole - č. 486 (lúbostná/rozlúčková), s. 351, spev: Agneša Pinkavová (SNK-LA, sign. A VII 21 002-21 003; súhlasí text aj melódia).

Všetky piesňové zápisy z obce Jablonica, ktoré Plicka uverejnil v tejto piesňovej zbierke, majú jednotne uvedený údaj o lokalite v podobe „Jablonica (okolie Trnavy), z vlast.[-ných] zápisov. “Ani pri jednej z nich však zberatel’v tlačenej zbierke neuvádza meno informátora, preto sme ho doplnili podla našich výskumov zo zápisov v SNM / SNK-LA. Z celkového počtu publikovaných piesní z Jablonice 7 zápisov má predlohy v rukopisných prameňoch, ktoré sa nachádzajú bud’ v Plickovej pozostalosti v SNM (3 zápisy), alebo v SNK-LA (4 zápisy).

\section{Spevák Pavol Pinkava a zápisy „zdobeného“ spevu}

V rámci dokumentácie ludového spevu v obci Jablonica sa Karol Plicka najviac sústredil na 52-ročného speváka Pavla Pinkavu, predstavitela staršej generácie. Z jeho repertoáru sa nám podarilo rekonštruovat 62 piesní vrátane tzv. „zdobených“ piesní.

12 PLICKA, Karol: Slovenský spevník I. 500 slovenských ludových piesní. Praha; Bratislava : Štátne hudobné vydavatel'stvo, 1961.

13 V tlači sa vyskytla chyba - pieseň pod č. 172 má zamenený melodický zápis s piesňou č. 173, čo potvrdzuje aj další text piesne. 
K. Plicka považoval tohto speváka za výnimočného, expresívne nadaného interpreta, čo potvrdzuje aj poznámka v Plickovej štúdii O zbieraní ludových piesní: ${ }^{14}$

„Ked' jablonický svat Pavel Pinkava zaspieva pri veselí, Sirota, sirota, tvoja svadba stojí, chápem, že neplače len sirota, ale plačú všetci okolo. Ked’zvážime, že jeho podanie (i podanie nemnohých iných) $v$ ničom sa neopiera ani o efektnú dynamiku, ani o hladané sostenuto a ritardando a vonkoncom už nie o cvičený hlas umelých spevákov, nemožno nám ani dost' hodnotit’ prekrásne, sýte espressivo $v$ hlase, ktoré je božským darom len ozajstných umelcov. "15

V súvislosti s týmto spevákom Karol Plicka uviedol v štúdii odkaz aj na Agnešu Pinkavovú a spôsob jej spevu zachytil v ukážke lúbostnej piesne Pri Dunajku šaty prala. ${ }^{16} \mathrm{Z}$ podania 35-ročnej speváčky Agneše Pinkavovej sme rekonštruovali spolu 40 piesní, pričom súčastou zápisu nápevov je aj ozdobnost', podobne ako u Pavla Pinkavu, hoci v prípade tejto speváčky aplikovaná v menšom rozsahu. Ozdobný spev sa nachádza najmä v svadobných piesňach (Hore háj, hore háj, Ideme, ideme, Od kostela do mlýna) a lúbostných piesňach (Beda temu kamenu), ale aj v baladách.

Aby sme pochopili, čo Plicka chápal pod označením tzv. „zdobený spev“, je potrebné spomenút jeho úvodnú štúdiu v Slovenskom spevníku I. ${ }^{17}$ Vysvetloval ho ako spôsob využitia niekol'kých druhov ozdôb, ktoré sa majú spievat l’ahko, a nie tažkopádne, ako sa často prezentujú na pôde folklorizmu. Tento spôsob zdobenia, tzv. „tichej noty“, sa má interpretovat’ v tradičnom prejave najmä mezzoforte alebo piano. ${ }^{18}$ Graficky Plicka rozlišoval, či je ozdoba nerozlučnou súčastou melódie (typické najmä pre piesne zo Záhoria a zvlášt’ pre speváka Pavla Pinkavu), a vtedy transkriboval tieto ozdoby normálnym typom nôt. Ozdoby tzv. „nahodenéc označoval malým typom nôt. ${ }^{19}$ Tento spôsob značenia sa nachádza nielen v tlačenej zbierke Slovenský spevník $I$, ale aj v jeho rukopisných zápisoch v SNM / SNK-LA. Z Plickových zápisov „zdobených“ piesní z podania Pavla Pinkavu môžeme spomenút napríklad baladu Jede Janénko pres hory, Na čačovskej rubanine, Počúvajte, hlavní pani, Stojí Kačka pri šentýši, V tej bakonskej hory.

K d’alším znakom tradičného prednesu „zdobených“ piesní patria tzv. tóny prechodné a prírazové, ${ }^{20}$ napríklad v zápise piesne Zaspívaj slávičku, rozveseluj pole (Slovenský spevník I, č. 486, s. 351; SNK-LA, sign. A VII 21 002-21 003). Tieto ozdoby treba spievat lahko a plynulo, aby nezatažili hlavnú melodickú líniu piesne. Zo zápisov piesní od P. Pinkavu je to napríklad vojenská pieseň Pod Verunú, pod tým kopcom. K melodickým ozdobám patria aj prírazy pred notou, čo je typické najmä pre zápis gajdošských piesní, napríklad: Ani som nezbíjal, Já sem synek sebevolný či Katerinka

14 PLICKA, Karol: O sbieraní ludových piesní. In: Sborník Matice Slovenskej 2, 1924, s. 49-59; prevzaté zo zborníka: SLIVKA, Martin: Karol Plicka o folklóre, fotografii, filme. Martin : Slovenské národné múzeum, 1994, s. 24-34.

15 PLICKA, Ref. 14, s. 28.

16 PLICKA, Ref. 14, s. 30.

17 Svoje chápanie ozdobného („zdobeného“) spevu Karol Plicka podrobne vysvetluje v úvodnej štúdii k piesňovej zbierke Slovenský spevník I. PLICKA, Ref. 12, s. 9-66.

18 PLICKA, Ref. 12, s. 41.

19 PLICKA, Ref. 12, s. 41-42.

20 PLICKA, Ref. 12, s. 42-43. 
husy pasla. Z d’alších typov ozdôb môžeme spomenút rôzne druhy obalov či opôr. ${ }^{21}$ Podla Plicku pri celkovom vyznení piesne však treba pamätat' hlavne na fakt, že ludový spevák svojimi ozdobami noty len obaluje, a nie zatažuje. V neposlednom rade je pri zdobenom speve dôležité legato (viazaný spôsob spevu), ktoré podla zberatelových názorov vychádza z hry na píštalách. Viaže sa nielen melódia, ale aj slovo. Za ideálny spôsob tohto typu spevu považuje Plicka interpretáciu Evy Studeničovej. ${ }^{22} \mathrm{Z}$ repertoáru Pavla Pinkavu sa legatové viazanie týka najmä lúbostných piesní, napríklad: Pri Trnave ruža kvitne, Mela sem já milovníčka, Ej, hory, hory; ale aj už spomenutých balád či svadobných piesní (Zadala mati, zadala ceru, Sirota, sirota, tvoja svadba stojí, Smutná noc, tmavá noc - „pre sirotu na svadbe“ atd.).

Niektoré zápisy piesní z podania speváka P. Pinkavu sú bez zdobeného spôsobu spevu, napríklad tanečné piesne (Každý kačer svú kačičku, Malučký je maderánek - túto pieseň Plicka charakterizuje ako „Jánošíkov odzemek“) a detské piesne (Hrábličky, hrábličky, Já sem malý jageríček). Niektoré zápisy z jeho repertoáru sa zasa vyznačujú malou mierou využitia zdobenia, napríklad svadobná legenda Veselí velké v Káni slaveno.

Plicka vo svojej štúdii upozorňuje aj na fakt, že pri tanečných piesňach sa môže pri prednese zo zápisu tvorit’ tvrdé, useknuté staccato, typické skôr pre novouhorské piesne. ${ }^{23}$ Tomuto sa treba vyhnút a staccato treba chápat skôr ako „položený prízvuk“, viac tušený, než ostro odseknutý. ${ }^{24} \mathrm{~V}$ neposlednom rade je pre záhorácke piesne dôležité glissando, ktoré Plicka vo svojich zápisoch presne zaznačuje s tým, odkial' a kam má smerovat, pričom je dôležité, aby pri interpretácii neskĺzlo príliš rýchlo, ale ani príliš pomaly. Pre tento spôsob spevu je preto nutné poznat' lokálny repertoár a jeho interpretačný štýl. ${ }^{25}$

Na základe rekonštrukcie piesňových zápisov z Jablonice, a najmä na príklade piesňového repertoáru speváka Pavla Pinkavu môžeme skonštatovat', že Plickove zápisy reprezentujú vzácny historický dokument ozdobného vokálneho štýlu, ktorého vrchol podla názorov niektorých bádatelov pravdepodobne kulminoval na Záhorí a v rakúskej oblasti Moravského pola v druhej polovici 19. storočia, pričom postupne zanikal v priebehu prvej tretiny nasledujúceho storočia. ${ }^{26}$

\section{Záver}

Rekonštrukcia zápisov ukázala, že v obci Jablonica Karol Plicka zaznamenal spolu 187 piesní. Žánrovej analýze sme podrobili piesňový repertoár v rozsahu 161 zápisov,

\footnotetext{
PLICKA, Ref. 12, s. 43.

PLICKA, Ref. 12, s. 43-44.

PLICKA, Ref. 12, s. 9-66.

PLICKA, Ref. 12, s. 48-49.

PLICKA, Ref. 12, s. 49-50.

26 Týmto štýlom spevu sa zaoberá štúdia od: MICHALOVIČ, Peter: Staršie zápisy ozdobného spevu na Záhorí a súčasný prístup k nim. In: Ethnomusicologicum 1/1. Ed. Stanislav Dúžek. Bratislava : ASCO, 1993, s. 87-94. K analýze fenoménu ozdobného spevu pozri bližšie: LOMEN, Kristina: Ozdobný spev Slovákov v Starej Pazove (Srbsko): dokumentácia, transkripcia, analýza, interpretácia. In: Musicologica Slovaca, roč. 12 (38), 2021, č. 2, s. 155-253.
} 
zvyšným 26 piesňam chýbala textová zložka. Napriek tomu sa dal na základe Plickových piesňových zápisov získat dostatočný prehlad o piesňovom repertoári tejto obce. Zberatel' sa sústredil na zachytenie lokálneho repertoáru od väčšieho počtu spevákov. Na základe pramennej kritiky sa nám podarilo identifikovat’ 26 mien spevákov. Čo sa týka generačného zastúpenia, Plicka pracoval so spevákmi širokého vekového rozptylu od 10-ročného dietata až po 58-ročného speváka. Aj ked’ medzi informátormi prevažujú ženy (22 speváčok), v celom dokumentovanom repertoári tejto obce dominujú piesňové zápisy od mužského predstavitela lokálnej piesňovej tradície Pavla Pinkavu. Zápisy piesní z podania tohto speváka tvoria reprezentatívnu zložku ozdobného spevu na Záhorí. Podobne ako v prípade speváčky Evy Studeničovej z Moravského Svätého Jána predstavujú vzácne historické doklady, ktoré sa stali dokumentom svojej doby. ${ }^{27}$

Štúdia je súčastou grantového projektu VEGA č. 2/0145/18 „Systematika piesňových žánrov v tradičnej hudobnej kultúre“ (2018 - 2021), riešeného v Ústave hudobnej vedy SAV.

${ }_{27}$ Ďakujem pracovníkom SNM a SNK-LA za sprístupnenie rukopisných zápisov Karola Plicku a za možnost' s nimi odborne pracovat'. 


\section{PRÍLOHA}

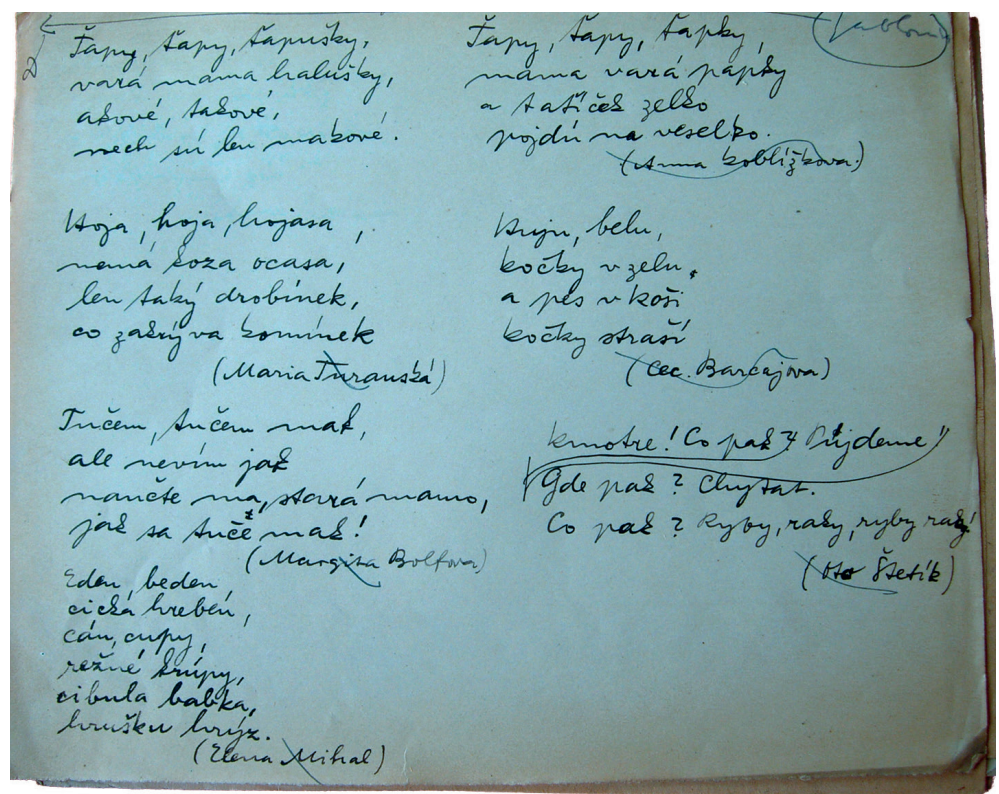

Obr. 1: Detské riekanky a vyčitanky, textový prvopis. Jablonica (okr. Senica). Prednes Maria Turanská, Margita Boltová, Elena Mihalová, Anna Koblížková, Cecila Barcajová, Oto Štebík (Pozostalost' K. Plicku, SNM v Martine)

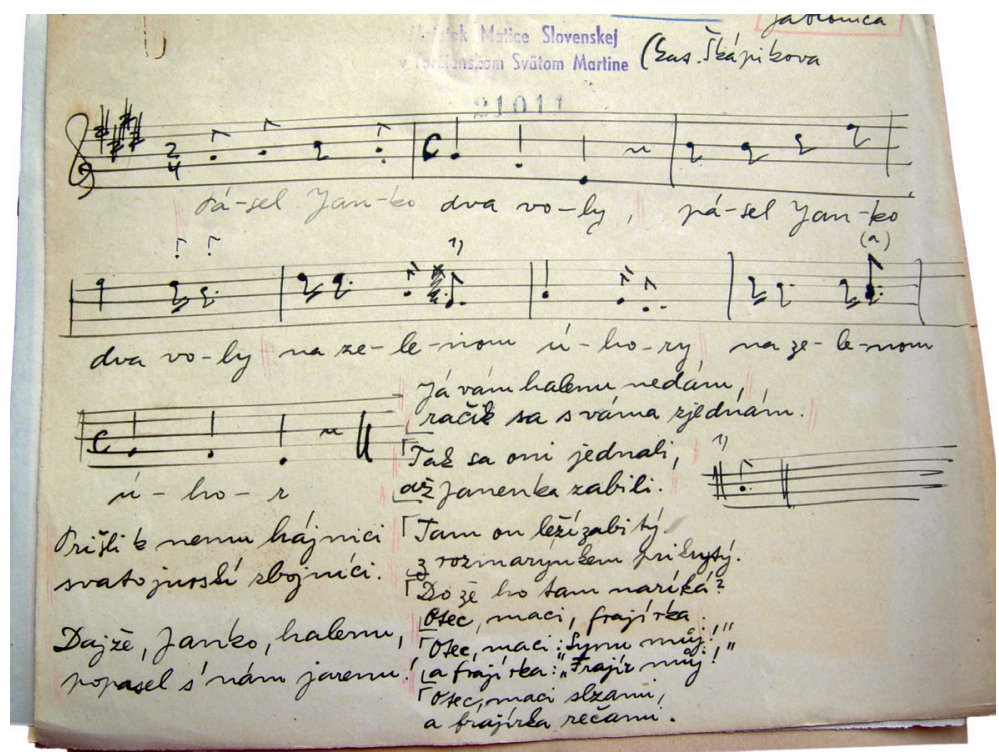

Obr. 2: Melodický čistopis piesne Pásel Janko dva voly, 1. var. Jablonica (okr. Senica). Spev Katarina Škápiková (Pozostalosṫ K. Plicku, SNM v Martine / [SNK-LA], sign. A VII 21 011) 


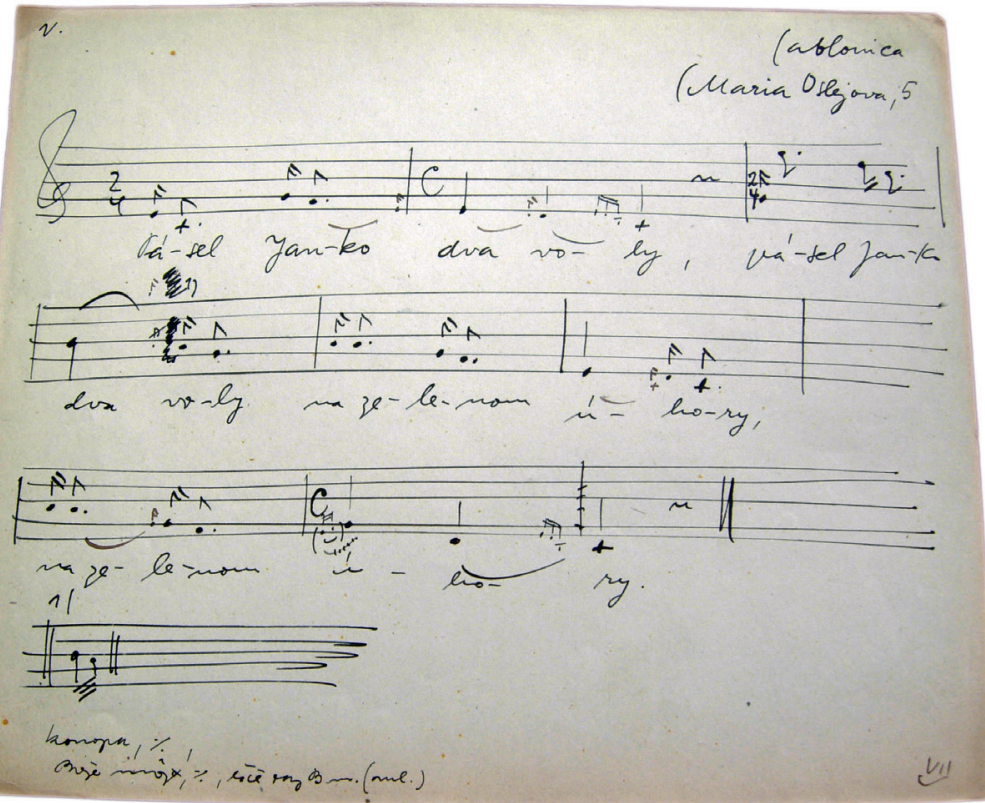

Obr. 3: Melodický čistopis piesne Pásel Janko dva voly, 2. var. Jablonica (okr. Senica). Spev Mária Oslejová (Pozostalost' K. Plicku, SNM v Martine)

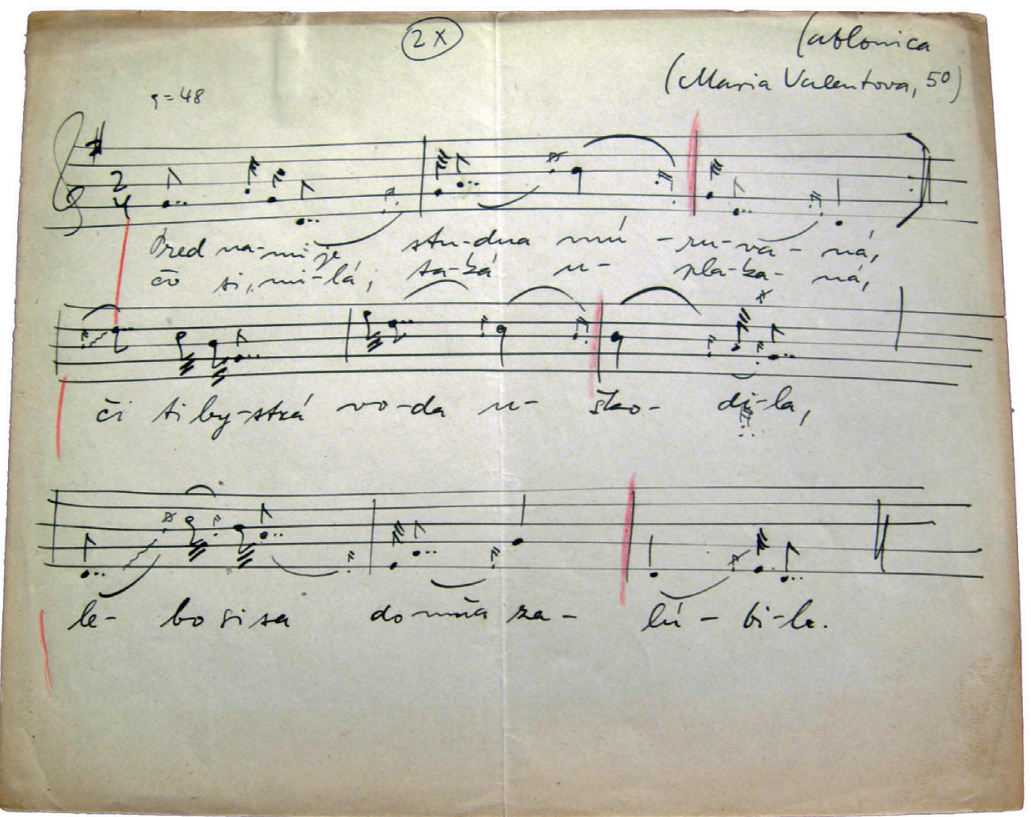

Obr. 4: Melodický čistopis piesne Pred nami je studna múruvaná. Jablonica (okr. Senica). Spev Mária Valentová (Pozostalost' K. Plicku, SNM v Martine) 


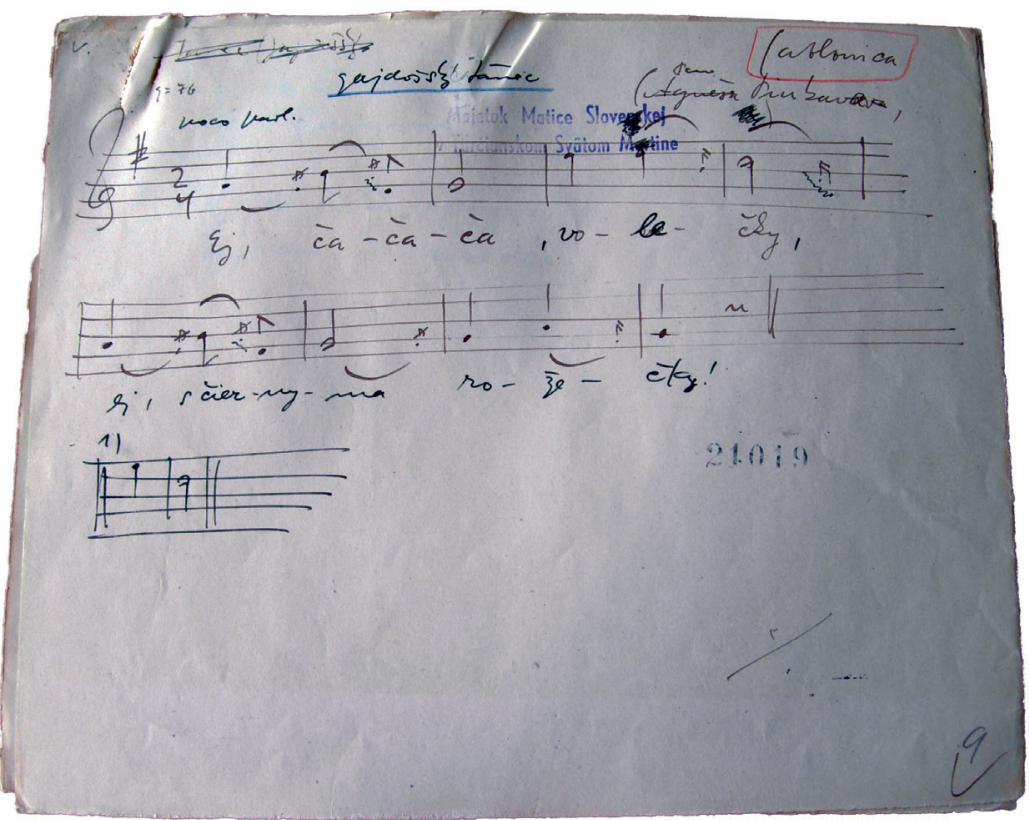

Obr. 5: Melodický čistopis piesne Ej, čačača, volečky. Jablonica (okr. Senica). Spev Agneša Pinkavová (SNKL-LA, sign. A VII 21 019)

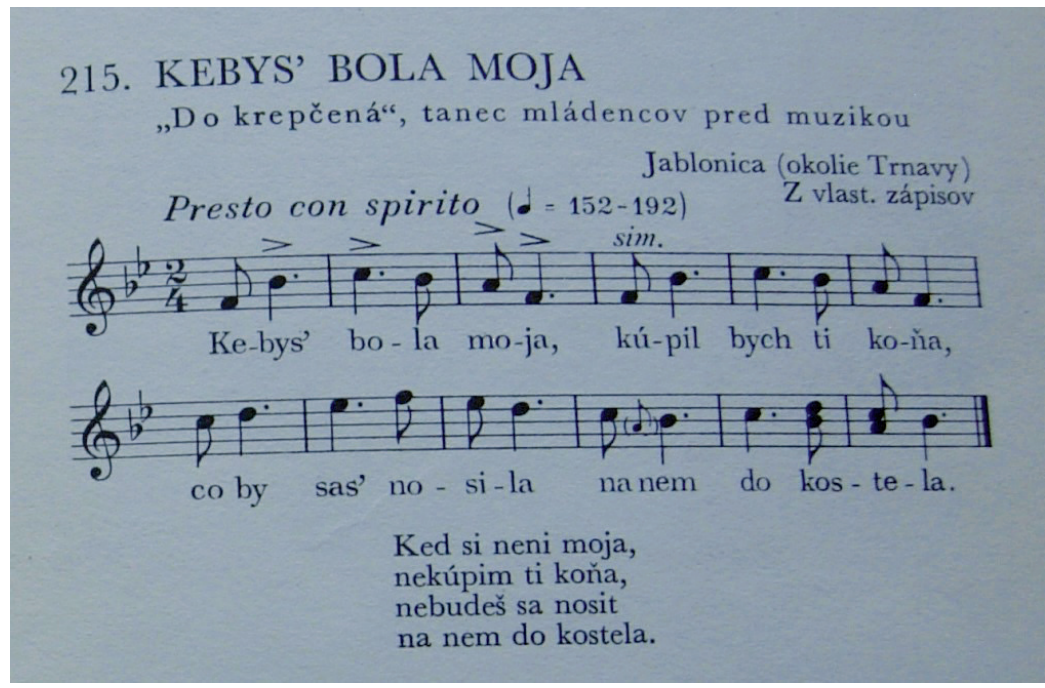

Obr. 6: Kebys' bola moja, tlačená verzia piesne. Jablonica (okr. Senica). (K. Plicka: Slovenský spevník I, 1961, č. 215, s. 195) 


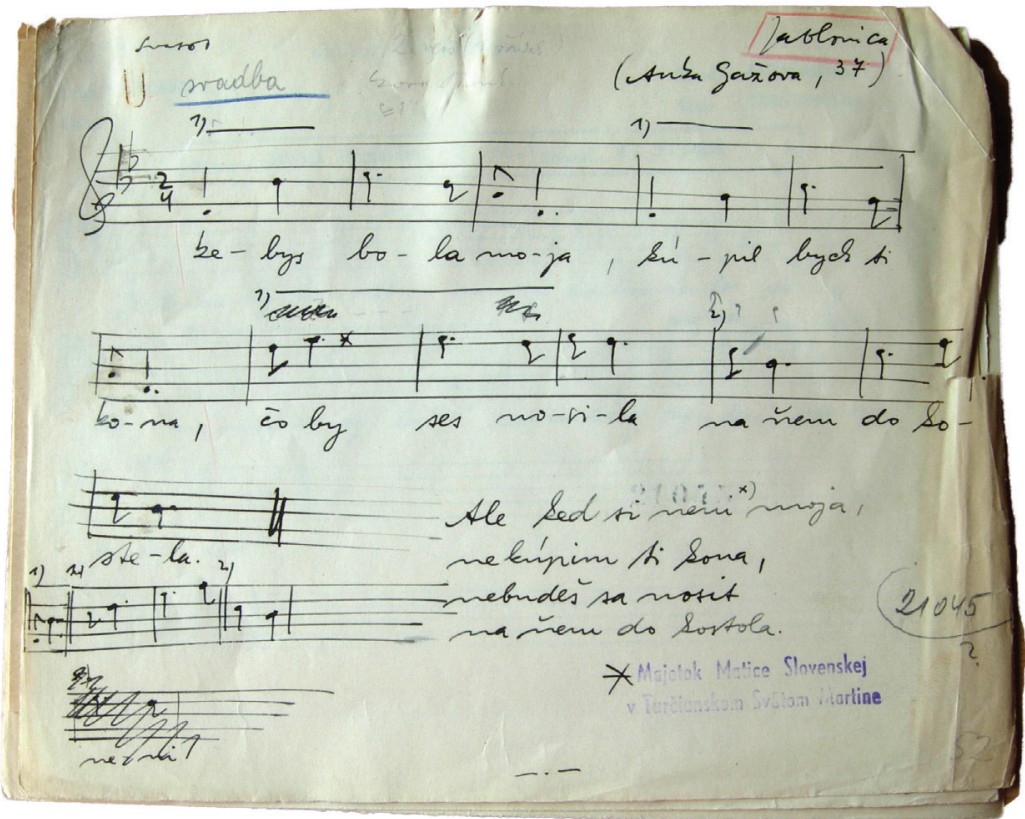

Obr. 7: Melodický čistopis piesne Kebys' bola moja. Jablonica (okr. Senica). Spev Anka Gažová (SNKL-LA, sign. A VII 21 045)

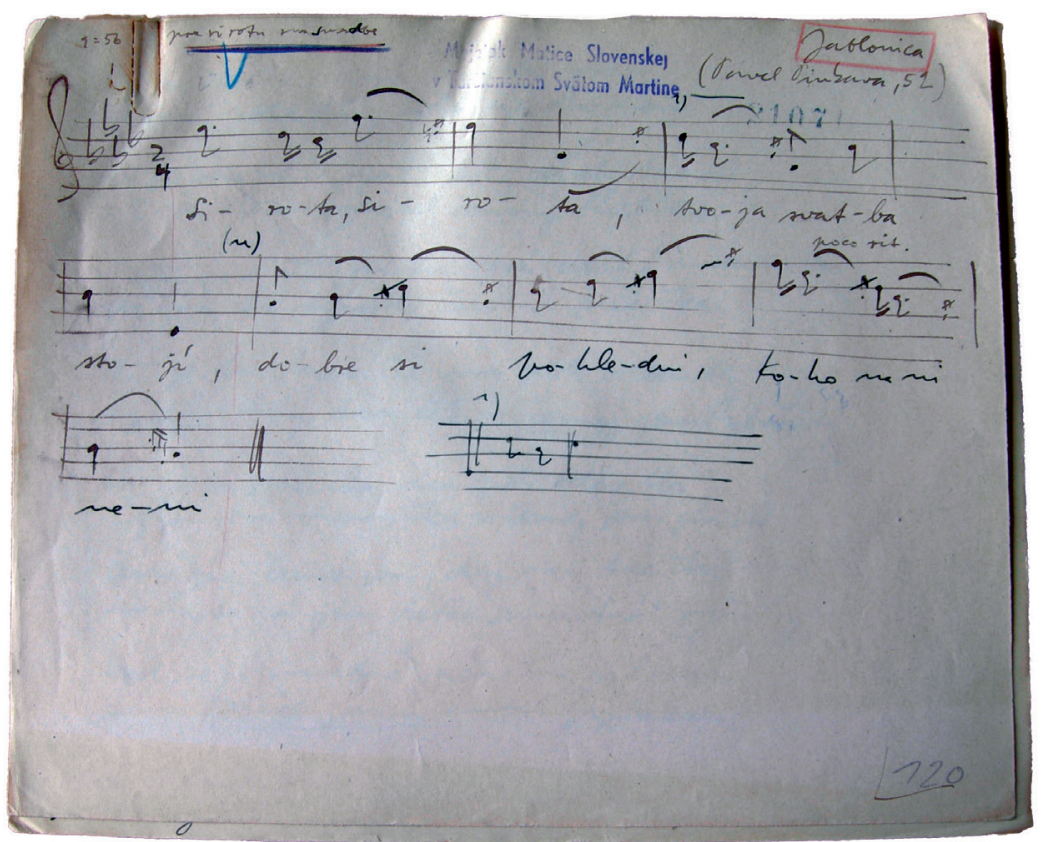

Obr. 8: Melodický čistopis piesne Sirota, sirota, 1. var. Jablonica (okr. Senica). Spev Pavel Pinkava (SNKL-LA, sign. A VII 21070 - 21 071) 


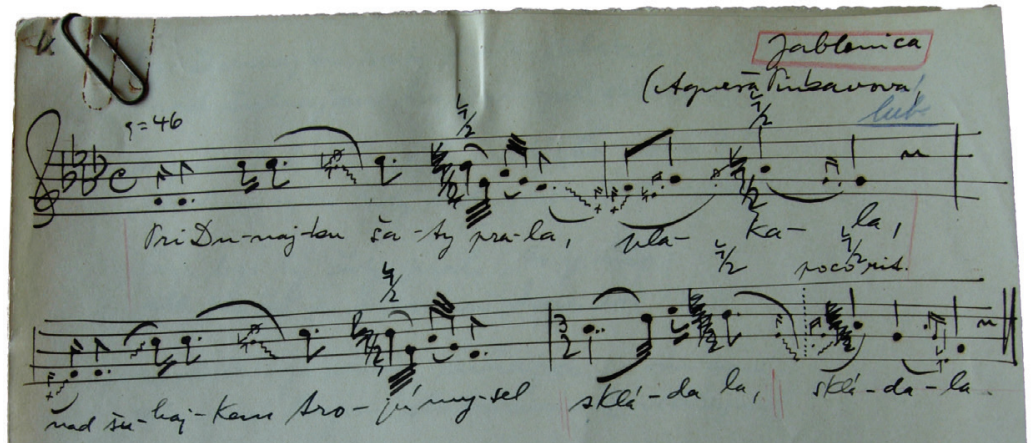

Obr. 9: Melodický čistopis piesne Pri Dunajku šaty prala. Jablonica (okr. Senica). Spev Agneša Pinkavová (SNKL-LA, sign. A VII 21 090)

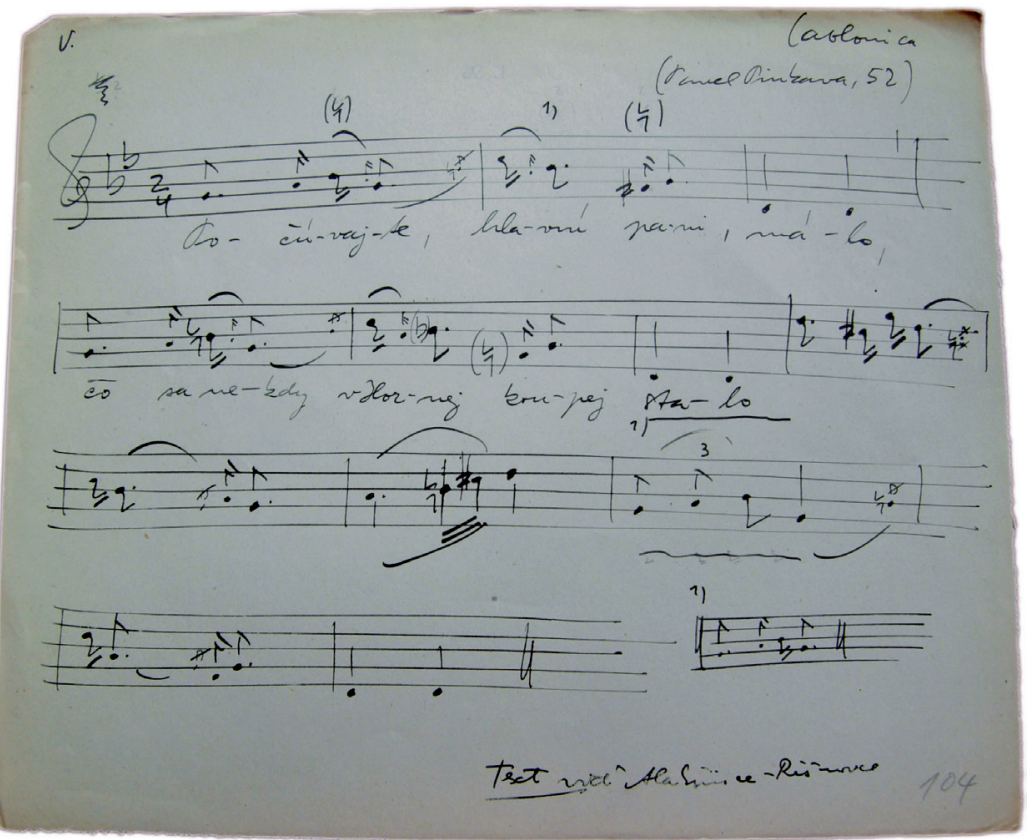

Obr. 10: Melodický čistopis piesne Počúvajte, hlavní pani. Jablonica (okr. Senica). Spev Pavel Pinkava (Pozostalost' K. Plicku, SNM v Martine) 


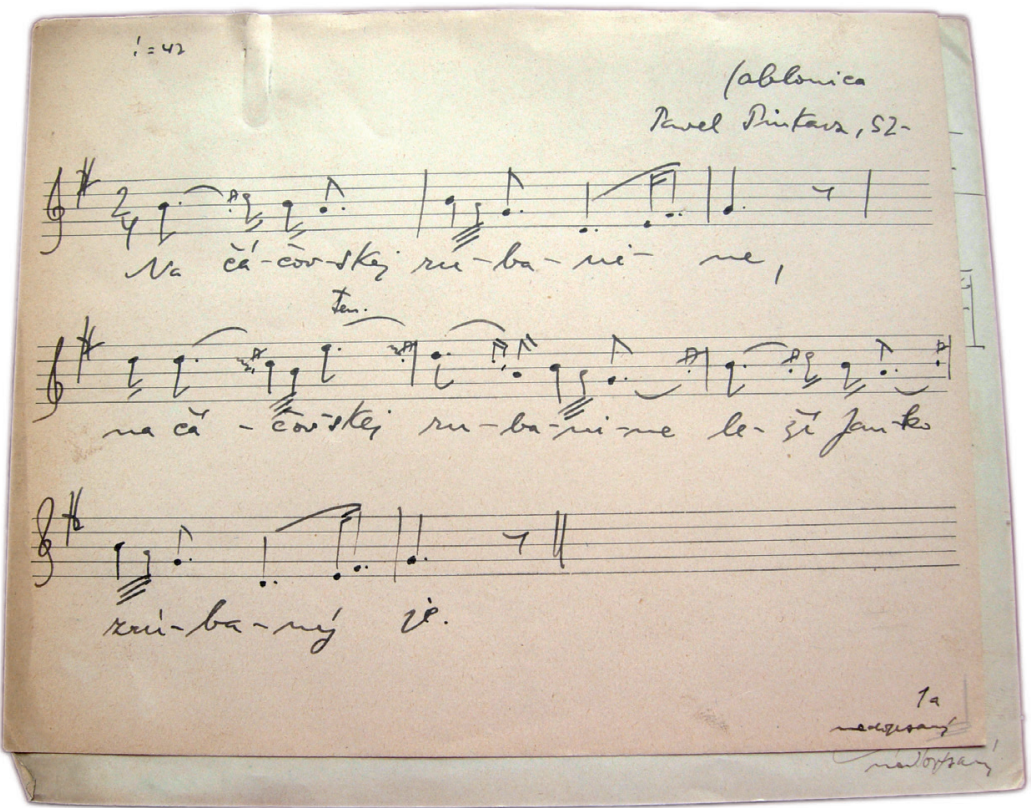

Obr. 11: Melodický čistopis piesne Na čáčovskej rubanine. Jablonica (okr. Senica). Spev Pavel Pinkava (Pozostalost' K. Plicku, SNM v Martine)

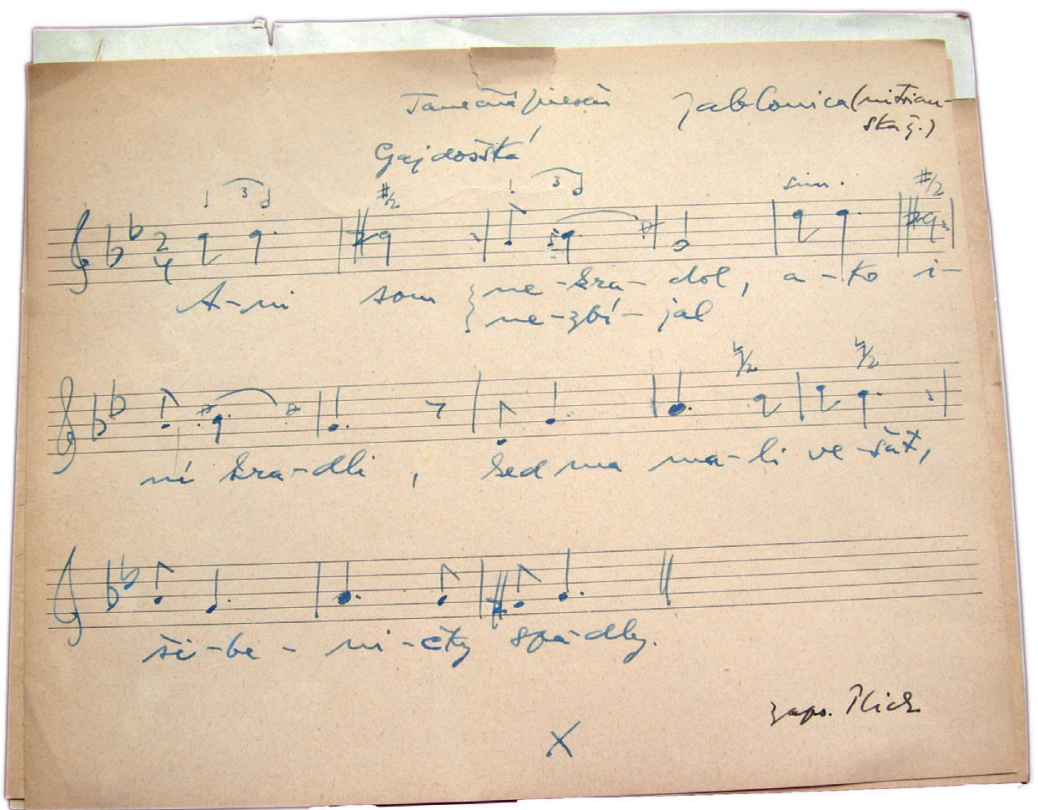

Obr. 12: Melodický čistopis piesne Ani som nezbijal. Jablonica (okr. Senica). Spev Pavel Pinkava (Pozostalost' K. Plicku, SNM v Martine) 


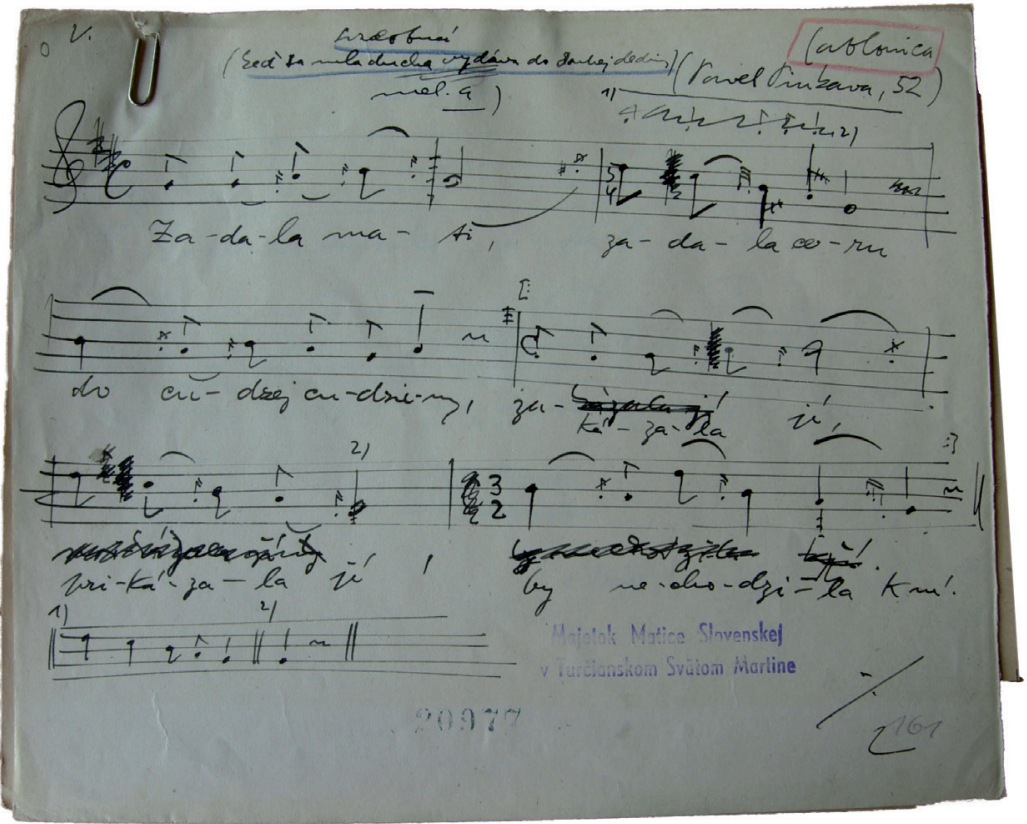

Obr. 13: Melodický čistopis piesne Zadala mati, zadala ceru, 1. var. Jablonica (okr. Senica). Spev Pavel Pinkava (SNKL-LA v Martine, sign. A VII 20 977)

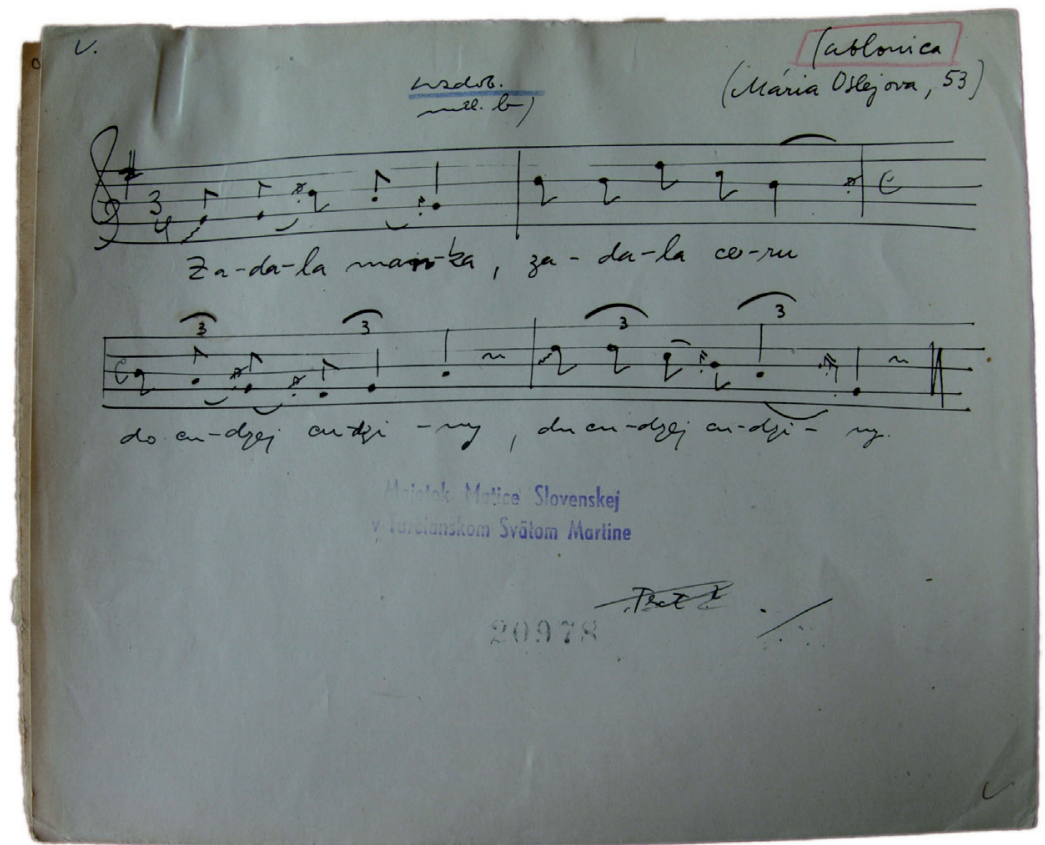

Obr. 14: Melodický čistopis piesne Zadala mati, zadala ceru, 2. var. Jablonica (okr. Senica). Spev Mária Oslejová (SNKL-LA, sign. A VII 20 978) 


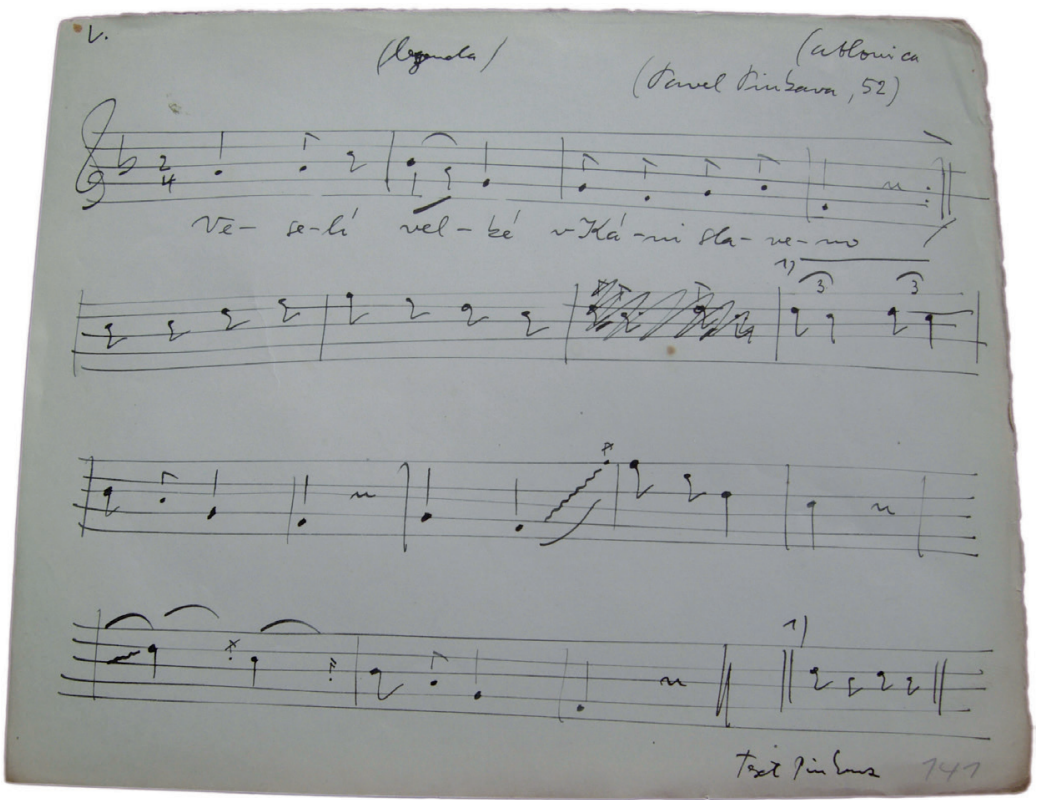

Obr. 15: Melodický čistopis piesne Veselí velké v Káni slaveno. Jablonica (okr. Senica). Spev Pavel Pinkava (Pozostalost' K. Plicku, SNM v Martine) 